\title{
Predicting dimensions of clinical-functional conditions and cognition in the elderly
}

\author{
Dimensões preditoras das condições clínico-funcionais e cognição em idosos \\ Dimensiones indicadoras de las condiciones clínico-funcionales y cognición en ancianos
}

Jenifer Nogueira Martins Araujo da Silva' ORCID: 0000-0002-5064-669X

Marinês Tambara Leite' ORCID: 0000-0003-3280-337X

Luana Caroline Gaviraghi" ORCID: 0000-0002-1447-7454

Vanessa Ramos Kirsten' ORCID: 0000-0002-6737-1039

Sandra da Silva Kinalski"' ORCID: 0000-0002-4841-2288

Leila Mariza Hildebrandt" ORCID: 0000-0003-0504-6166

Margrid Beuter"I

ORCID: 0000-0002-3179-9842

'Universidade Federal de Santa Maria. Palmeira das Missões, Rio Grande do Sul, Brazil.

"Associação Hospital de Caridade de Palmeira das Missões.

Palmeira das Missões, Rio Grande do Sul, Brazil. "'Universidade Federal de Santa Maria. Santa Maria, Rio Grande do Sul, Brazil.

How to cite this article: Silva JNMA, Leite MT, Gaviraghi LC, Kirsten VR, Kinalski SS, Hildebrandt LM, et al. Predicting dimensions of clinicalfunctional conditions and cognition in the elderly. Rev Bras Enferm. 2020;73(Suppl 3):e20190162. doi: http://dx.doi.org/10.1590/0034-7167-2019-0162

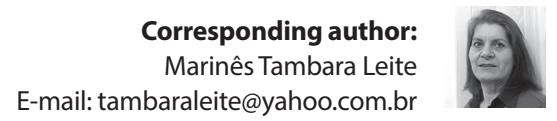

EDITOR IN CHIEF: Dulce Barbosa ASSOCIATE EDITOR: Maria Saraiva

\begin{abstract}
Objective: To evaluate the predictive dimensions of clinical-functional conditions and the cognitive capacity of elderly people living at home. Method: Cross-sectional, populationbased, analytical, quantitative study was utilized. For data collection, an instrument with sociodemographic and behavioral variables, the Functional Clinical Vulnerability Index; and, to assess cognition, the Mini-Mental State Examination (MMSE) was used. Descriptive analyzes and statistical tests were conducted. Results: 305 elderly subjects, living at home, in urban and rural areas participated in the study. They were classified as robust (71.8\%), pre-frail (22\%) and frail (6.2\%). As for cognition, $24.9 \%$ of them had cognitive impairment. It was shown that cognitive impairment predicts the development of functional disability. Conclusion: It is considered that health professionals should both act in order to maintain the functional and cognitive conditions of the robust and pre-frail elderly people and pay attention to the rehabilitation of the disabilities installed in those elderly people who are in a situation of frailty. Descriptors: Aged; Frailty; Health of the Elderly; Nursing; Cognition.
\end{abstract}

\section{RESUMO}

Objetivo: Avaliar as dimensões preditoras das condições clínico-funcionais e a capacidade cognitiva de idosos residentes no domicílio. Métodos: Estudo transversal de base populacional, analítico, quantitativo. Para coleta de dados, utilizou-se: instrumento com variáveis sociodemográficas e comportamentais, o Índice de Vulnerabilidade Clínico Funcional; e, para avaliar a cognição, o Mini Exame do Estado Mental. Foram conduzidas análises descritivas e testes estatísticos. Resultados: Participaram do estudo, 305 idosos, residentes no domicílio, em área urbana e rural. Eles classificaram-se em robustos $(71,8 \%)$, pré-frágeis $(22 \%)$ e frágeis $(6,2 \%)$. Quanto à cognição, $24,9 \%$ deles apresentaram déficit cognitivo. Evidenciou-se que o comprometimento cognitivo prediz o desenvolvimento de incapacidade funcional. Conclusão: Considera-se que os profissionais de saúde devem tanto atuar no sentido da manutenção das condições funcionais e cognitivas dos idosos robustos e pré-frágeis quanto atentar para a reabilitação das incapacidades instaladas naquelas pessoas idosas que se encontram em situação de fragilidade. Descritores: Idoso; Fragilidade; Saúde do Idoso; Enfermagem; Cognição.

\section{RESUMEN}

Objetivo: Evaluar las dimensiones indicadoras de las condiciones clínico-funcionales y la capacidad cognitiva de ancianos residentes en el domicilio. Método: Estudio transversal de base poblacional, analítico, cuantitativo. Para recogida de datos, se ha utilizado: instrumento con variables sociodemográficas y comportamentales, el Índice de Vulnerabilidad Clínico Funcional; y, para evaluar la cognición, el Mini Examen del Estado Mental. Han sido conducidos análisis descriptivos y test estadísticos. Resultados: Participaron del estudio, 305 ancianos, residentes en el domicilio, en área urbana y rural. Ellos se clasificaron en robustos $(71,8 \%)$, prefrágiles (22\%) y frágiles (6,2\%). En cuanto a la cognición, $24,9 \%$ de ellos presentaron déficit cognitivo. Se ha evidenciado que el comprometimiento cognitivo predice el desarrollo de incapacidad funcional. Conclusión: Se considera que los profesionales de salud deben tanto actuar en el sentido de la manutención de las condiciones funcionales y cognitivas de los ancianos robustos y pre-frágiles cuanto atentar para la rehabilitación de las incapacidades instaladas en aquellas personas ancianas que se encuentran en situación de fragilidad. Descriptores: Anciano; Fragilidad; Salud del Anciano; Enfermería; Cognición. 


\section{INTRODUCTION}

Populational aging has been increasing progressively and intensely, above all in developing countries, such as Brazil. Aging is a natural process of human beings, not one which multifactorial changes occur from a physical, psychological and social point of view, that reverberates in the life of the aging people and interfere in the relationship between the self, the mind and society, not having to be considered a disease ${ }^{(1)}$.

Characterizing aging as a continuum means that aging occurs daily, without that having a sense of being old ${ }^{(2)}$. For your lifespan, as it continues, is acquired to be lived, so must be lived with a quality of life. Among the aspects related to the quality of life in old age, functional capacity (FC) which is associated with independence and autonomy of the individual ${ }^{(3)}$.

The potential that the elderly people present to decide to act independently is not defined as FC. This attribute can be endorsed in different ways and perspectives. Like this, a functional assessment, verifies, in a systematized way, that the levels of the provisions and the restrictions restrict the weight of people to carry out, in an autonomous and independent way, the activities of daily living (ADLs) and make possible the elaboration of a more suitable assistance plan ${ }^{(4)}$. It is important to point out that the reduction of $\mathrm{FC}$ and the autonomy of elderly people may imply negative consequences for them, such as modifying their way of life and overloading their families and/or their caregivers ${ }^{(5)}$.

Independence is understood as the ability to perform functions related to daily life, this is, having the capacity to live independently in a community with some or no help from other people. And autonomy is the ability to control, deal with and make decisions about how you want to live, according to your own rules and preferences ${ }^{(4)}$. In this context, the quality of life $(\mathrm{QL})$ is a broad concept that encompasses physical health, the level of independence, social relationships, the psychological state, personal beliefs and the environment. The World Health Organization (WHO) defined QL as a perception that the person has about their position in life, inserted into their community and in the system of values, relative to their expectations, standards and concerns ${ }^{(4)}$.

The aging process could cause diminution of the $\mathrm{FC}$ and make the elderly person lose their autonomy and independence, compromising their quality of life ${ }^{(6)}$. At the same time, the development of chronic diseases has been growing among the elderly, and this is due, in part, to the process of population aging, of which commonly occurs in a healthy way, but also due to the possibility of interface with chronic-degenerative morbidities, which we can accredit to the loss of FC, leaving them vulnerable and dependent on care ${ }^{(7)}$.

Frailty is a multidimensional syndrome, which involves biological, cognitive and social factors, culminating in the state of greatest vulnerability, associated with the greatest risk of adverse clinical deficiencies (functional decline, falls, hospitalization, institutionalization and death). Frailty is related to the presence of comorbidities and disabilities and may be the cause or predispose to such events ${ }^{(8-9)}$. The elderly people classified as frail can present three or more following characteristics: fatigue account, weight loss with no apparent cause over the period of one-year, reduced capacity for physical activity, reduced grip strength and change in gait and balance ${ }^{(9)}$. In this way, it is important to verify the occurrence of the frailty syndrome in this population, as well as identifying which causes are associated with this vulnerability. Among them, the cognitive decline receives greater emphasis ${ }^{(10)}$.

Cognitive decline consists in slowing down of mental abilities, which evolves as age advances, can relate to the biological losses inherent in time and, in addition, be associated with other reasons, such as: dementia, medication use, altered affect and depression. The cognitive deficits observed in aging are forgetfulness of recent facts, difficulty in making calculations, changes in the state of attention, decreased concentration and reasoning ${ }^{(11)}$.

A cognitive assessment of $\mathrm{FC}$ is relevant in the area of geriatrics and gerontology as a tool for estimating the quality of life of the elderly ${ }^{(12)}$. This assessment can be carried out systematically in health care services for the elderly, using instruments already built and validated.

In these services, the nurses play an important role together with this population, once they interact and share the orientations, offering differentiated, humanized and qualitative assistance to this population stratum. In addition, they assist the elderly in maintaining functional and cognitive capacity, coping with situations of illness and finding meaning in life.

\section{OBJECTIVE}

Evaluate the clinical-functional conditions and the cognitive capacity of elderly residents in rural and urban areas of a municipality in Rio Grande do Sul.

\section{METHODS}

\section{Ethical aspects}

In the course of the research, the provisions of Resolution CNS/MS n'. 466/2012 ${ }^{(17)}$ were preserved and the project, was submitted and approved for its execution by the Ethics and Research Committee.

\section{Design, study location, period, population and sample}

This was a cross-sectional study with a population-based, quantitative basis, with the convenient sample, conducted in a municipality of Rio Grande do Sul, Brazil, where the data was collected at the subject's residence, in the period from January to February 2018. Participants in this study were elderly residents in the urban and rural areas of the investigation's local municipality.

The total population of the municipality was 2,710 , of which 1,858 lived in the rural area; and 852, in the urban area ${ }^{(13)}$. According to data from the Brazilian Institute of Geography and Statistics (IBGE), this municipality had, in 2010, $13.9 \%$ of individuals aged 60 years or over ${ }^{(13)}$. From the population data updated by the Community Health Agents (CHA) in September 2017, the sample size of elderly subjects was 406 , distributed in seven micro areas of action of the Family Health Strategy (FHS). The location and address of the elderly subjects were provided by the $\mathrm{CHA}$, which also accompanied the researcher in conducting the interviews. It is noteworthy that the municipality had $100 \%$ coverage by the FHS. However, in the period of data collection, a micro area was 
without coverage, without $\mathrm{CHA}$, made contact unviable and the interview with 62 elderly subjects assigned to this FHS. Beyond this, 39 elderly people linked to other FHSs were not at home when the interviewer visited. Thus, 305 elderly subjects participated in this study. Thus, 305 elderly people participated in this study.

\section{Inclusion and exclusion criteria}

The inclusion criteria were established: being elderly, living in an area covered by the local municipality, place of study. In case of cognitive impossibility of the elderly to carry out the interviews, the information regarding the sociodemographic characterization and the IVCF-20 were provided by a relative and/or their caregiver. In these cases, the MMSE was not applied.

\section{Study protocol}

For data collection, a questionnaire was used to characterize the population, elaborated by the researchers - the Clinical-Functional Vulnerability Index-20 (IVCF-20); and the Mini-Mental State Examination (MMSE). The questionnaire contained questions related to socioeconomic data and health. To assess the risk of vulnerability, the Clinical-Functional Vulnerability Index-20 (IVCF-20) was used. This questionnaire covered multidimensional aspects of the health condition of the elderly, consists of 20 questions divided into eight sections: age (1 question), self-perceived health (1 question), functional disabilities (4 questions), cognition (3 questions), mood (2 questions), mobility (6 questions), communication (2 questions) and multiple comorbidities (1 question). Each section had a specific score with a maximum value of 40 points. The higher the value obtained, the greater the risk of clinical-functional vulnerability of the elderly ${ }^{(14)}$. The elderly with low risk of clinical-functional vulnerability (robust) were classified as those with scores from 0 to 6 points; with moderate risk (pre-frail), with scores of 7 to 14 ; and with high risk of clinical-functional vulnerability (frail), with a score of 15 or more ${ }^{(14)}$.

To evaluate the cognitive level, the Mini-Mental State Examination (MMSE) ${ }^{(15)}$ was used. This instrument contains questions grouped into seven categories, and each had the objective of evaluating specific cognitive "functions" such as: temporal orientation (5 points), spatial orientation (5 points), three-word registration (3 points), attention and calculation ( 5 points), memory of the three words (3 points), language (8 points) and visual constructive capacity (1 point). The MMSE score ranges from 0 points (highest degree of cognitive impairment of individuals) to a maximum total of 30 points (best cognitive ability) ${ }^{(15-16)}$. As education influences the MMSE scores, in this study the cut-off score was used according to the number of years of formal study ${ }^{(16)}$, which are: 18 points for illiterates; 21 points for individuals with schooling from 1 to 3 years; 24 points from 4 to 7 years; and 26 points for those with 7 years or more of formal education.

\section{Analysis of results and statistics}

The collected data was double digitized in a database, to avoid possible typing errors. Subsequently, for analysis, the software, Statistical Package for the Social Sciences (SPSS), version 21.0 was used. Descriptive statistical analysis was used, with frequency distribution (for qualitative variables); and associations between categorical variables were performed using chi-square tests and Fischer's exact test. It was adopted a value of $p<0.05$ as a level of significance for all analyzes.

\section{RESULTS}

Of the 305 elderly study subjects, 229 (75.1\%) did not present cognitive impairment, and 219 (71.8\%) were classified as robust. Among the elderly subjects who were classified as frail, 13 (17.1\%) had cognitive impairments, whereas, among those classified as robust, $178(77.7 \%)$ maintained their unaltered cognitive ability ( $p$ $<0.000$ ). This data evidence that a reduction of clinical-functional conditions is associated with cognitive deficit (Table 1).

Table 1 - Classification of the elderly according to IVCF-20, according to the presence or absence of cognitive impairment (MMSE), 2018

\begin{tabular}{ccccc}
\hline & \multicolumn{4}{c}{ COGNITION } \\
IVCF-20 & $\mathbf{n}(\%)$ & $\begin{array}{c}\text { Without deficit } \\
\mathbf{n}(\%)\end{array}$ & $\begin{array}{c}\text { With deficit } \\
\mathbf{n}(\%)\end{array}$ & $\boldsymbol{p}$ value \\
\hline Robust & $219(71.8)$ & $178(77.7)$ & $41(53.9)$ & \\
Pre-frail & $67(22.0)$ & $45(19.7)$ & $22(28.9)$ & $0.000^{*}$ \\
Frail & $19(6.2)$ & $6(2.6)$ & $13(17.1)$ & \\
Total & $305(100)$ & $229(75.1)$ & $76(24.9)$ & \\
\hline Note: ${ }^{*}$ Chi-square test, $p<0.05$. & &
\end{tabular}

It can be seen in Table 2, that among the elderly subjects who presented cognitive impairment, 44 (29.9\%) considered their health to be regular or poor; among those who did not have cognitive changes, 126 (79.7\%) considered it excellent or good. As for instrumental activities of daily living (IADL), 275 (90.2\%) reported that their health or physical condition did not prevent them from shopping; and 283 (92.8\%) reported they did not stop controlling their money or paying bills $(p<0.000)$.

Among the elderly with cognitive impairment, 19 (86.4\%) reported having stopped shopping or paying bills because of their health. As for the performance of small domestic tasks, $20(71.4 \%)$ elderly subjects did not perform them, a statistically significant result $(p<0.000)$. Regarding ADLs, like bathing alone, $296(97.0 \%)$ reported not having done it $(p<0.001)$.

With regards to mood, of the elderly subjects without cognitive impairment, $53(71.6 \%)$ reported discouragement, sadness or hopelessness in the last month. As for mobility, 211 (77.3\%) of the elderly without cognitive impairment and $62(22.7 \%)$ of those presenting cognitive impairment, reported difficulties in walking. With regards to falls, 294 (96.4\%) of the total of elderly subjects did not present them in the last year. With regards to sphincter continence, 290 (95.1\%) stated that they did not accidentally release urine or faeces $(p<0.001)$.

The data related to communication show that 293 (96.1\%) elderly people did not report sufficient vision problems to prevent the performance of some daily activity and 292 (95.7\%) also did not mention hearing problems. However, of the elderly subjects with cognitive impairment, eight (61.5\%) reported hearing problems.

The data related to the dimensions of the IVCF-20 and age group showed that $22(50 \%)$ of the elderly subjects over 80 years old were classified as pre-frail, and $8(18.2 \%)$ are frail (Figure 1). This data shows that age is a predictor of reduced functional capacity. 
Table 2 - Distribution of the elderly according to IVCF-20 and the presence or absence of cognitive impairment, 2018

\begin{tabular}{|c|c|c|c|c|}
\hline \multirow[b]{2}{*}{ IVCF-20 } & \multirow[b]{2}{*}{ n (\%) } & \multicolumn{2}{|c|}{ Cognition } & \multirow[b]{2}{*}{$\begin{array}{c}p \\
\text { value }\end{array}$} \\
\hline & & $\begin{array}{l}\text { Without } \\
\text { deficit } \\
\text { n (\%) }\end{array}$ & $\begin{array}{l}\text { With } \\
\text { deficit } \\
\text { n (\%) }\end{array}$ & \\
\hline
\end{tabular}

In general, would you say your health is...

Excellent, very good or good Regular or bad.

$158(51.8) \quad 126(79.7) \quad 32(20.3) \quad 0.034^{*}$

Due to your health or physical condition, have you stopped shopping?

Yes

No or doesn't go shopping for other reasons

Has your health stopped you

from controlling your finance and

paying your bills?

Yes

No or doesn't control for other reasons

$147(48.2) \quad 103(70.1) \quad 44(29.9) \quad 0.034$

Due to of your health you have stopped doing small domestic chores?

No or for other reasons

Due to of your health or physical condition, have you stopped showering alone?

Yes

No

Did a family member or friend

say that you are becoming

forgetful?

Yes

No

Is this forgetfulness getting worse in recent months?

Yes

No

Is this forgetfulness preventing the completion of any daily activity?

Yes

No

In the last month, have you felt discouraged, sad or hopeless?

Yes

No

In the last month, you have

lost interest or pleasure in

pleasurable activities?

Yes

No

Do you have difficulty walking?

Yes

No

Have you had two or more falls in the past year?

Yes

No

Do you accidentally release urine

or faeces at some point?

Yes

No

$30(9.8) \quad 10(33.3) \quad 20(66.7)$

$275(90.2) \quad 219(79.6) \quad 56(20.4) \quad 0.000^{*}$

$\begin{array}{cccc}22(7.2) & 3(13.6) & 19(86.4) & \\ 283(92.8) & 226(79.9) & 57(20.1) & 0.000^{*}\end{array}$

$28(9.2) \quad 8(28.6) \quad 20(71.4)$

$277(90.8) \quad 221(79.8) \quad 56(20.2) \quad 0.000^{*}$

$9(3.0) \quad 2(22.2) \quad 7(77.8)$

$296(97.0) \quad 227(76.7) \quad 69(23.3) \quad 0.001^{*}$

$123(40.3) \quad 89(72.4) \quad 34(27.6)$

$182(59.7) \quad 140(76.9) \quad 42(23.1)$

0.220

$56(18.4) \quad 35(62.5) \quad 21(37.5)$

$18(5.9) \quad 7(38.9) \quad 11(61.1)$

$287(94.1) \quad 222(77.4) \quad 65(22.6) \quad 0.001^{*}$

$74(24.3) \quad 53(71.6) \quad 21(28.4)$

$231(75.7) \quad 176(76.2) \quad 55(28.4)$

0.260

$22(7.2) \quad 11(50.0) \quad 11(50.0) \quad 0.007^{*}$ $283(92.8) \quad 218(77.0) \quad 65(23.0)$

$32(10.5) \quad 18(56.2) \quad 14(43.8) \quad 0.011^{*}$ $273(89.5) \quad 211(77.3) \quad 62(22.7)$
Predicting dimensions of clinical-functional conditions and cognition in the elderly Silva JNMA, Leite MT, Gaviraghi LC, Kirsten VR, Kinalski SS, Hildebrandt LM, et al.

Table 2 (concluded)

\begin{tabular}{ccccc}
\hline & \multicolumn{3}{c}{ Cognition } \\
IVCF-20 & $n(\%)$ & $\begin{array}{c}\text { Without } \\
\text { deficit }\end{array}$ & $\begin{array}{l}\text { With } \\
\text { deficit }\end{array}$ & $\begin{array}{c}p \\
\text { value }\end{array}$ \\
& $n(\%)$ & $n(\%)$ & \\
\hline
\end{tabular}

Do you have vision problems that

can prevent you from carrying

out daily activity?

Yes

No

$\begin{array}{cccc}12(3.9) & 6(50.0) & 6(50.0) & 0.050^{*} \\ 293(96.1) & 223(76.1) & 70(23.9) & \end{array}$

Do you have hearing problems

that can prevent carrying out

daily activity?

Yes

No

$13(4.3) \quad 5(38.5) \quad 8(61.5)$

$292(95.7) \quad 224(76.7) \quad 68(23.3)$

$0.005^{*}$

Total

$305(100) \quad 229(75.1) \quad 76(24.9)$

Note: * Fischer's exact test; Significant value equal to $p<0.05$.

Figure 2, demonstrates that the elderly subjects who attended formal education longer were classified as robust 64 (78\%). In this scenario, it appears that education is a protective factor for the preservation of clinical-functional conditions and cognition in the elderly.

$249(81.6) \quad 194(77.9) \quad 55(22.1) 0.015^{*}$

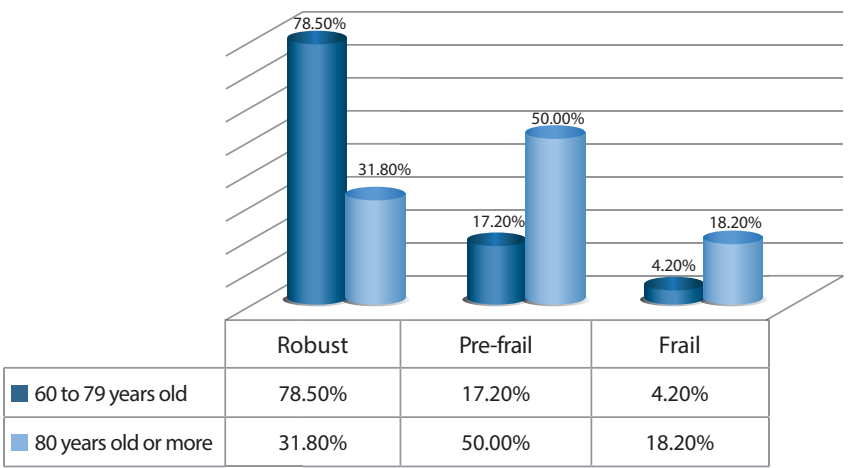

Figure 1 - Distribution of participants according to the dimensions of the AVCF-20 and age group, 2018

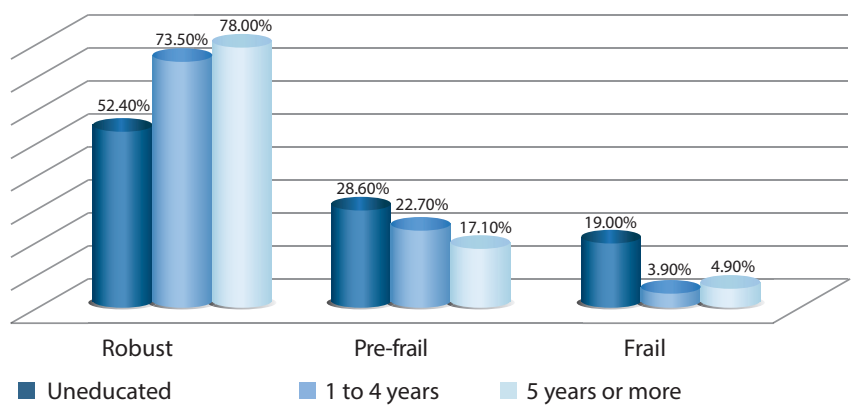

Figure 2 - Distribution of participants according to the dimensions of the IVCF-20 and education, 2018

Table 3 shows that the predominant age group was 60 to 69 years old with 161 (52.8\%) participants; 93 (57.1\%) were women; 197 (64.6\%) lived in rural areas; 198 (64.9\%) were married; 278 (91.1\%) mentioned having children; and 42 (13.8\%) did not study.

As for the occupational situation, 246 (80.7\%) were retired, and 59 (19.3\%) mentioned working and/or being retired. The monthly income of 227 (74.4\%) varied from a minimum wage or less; and 223 (74.3\%) had 2 to 3 people dependent on the income they received. 
Table 3 - Distribution of study participants, according to sociodemographic characteristics and sex, 2018

\begin{tabular}{|c|c|c|c|c|}
\hline & n (\%) & $\begin{array}{c}\text { Feminine } \\
\text { n (\%) }\end{array}$ & $\begin{array}{c}\text { Masculine } \\
\text { n (\%) }\end{array}$ & $\begin{array}{c}p \\
\text { value }\end{array}$ \\
\hline \multicolumn{5}{|l|}{ Age } \\
\hline 60 to 70 & $161(52.8)$ & $93(57.1)$ & 68 (47.9) & \\
\hline 70 to 80 & $100(32.8)$ & $53(32.5)$ & $47(33.1)$ & 0.078 \\
\hline 80 or over & $44(14.4)$ & $17(40.4)$ & $27(19.0)$ & \\
\hline \multicolumn{5}{|l|}{ Marital status } \\
\hline Married & $198(64.9)$ & $101(62.0)$ & $97(68.3)$ & \\
\hline Single & $40(13.1)$ & $20(12.3)$ & $20(14.1)$ & 0.227 \\
\hline Widowed & $67(22.0)$ & $42(25.8)$ & $25(17.6)$ & \\
\hline \multicolumn{5}{|l|}{ Residence } \\
\hline Urban & $108(35.4)$ & $64(39.3)$ & $44(31.0)$ & 0.132 \\
\hline Rural & $197(64.6)$ & $99(60.7)$ & $98(69.0)$ & \\
\hline \multicolumn{5}{|l|}{ Children } \\
\hline Yes & $278(91.1)$ & $152(93.3)$ & $126(88.7)$ & 0.166 \\
\hline No & $27(8.9)$ & $11(6.7)$ & $16(11.3)$ & \\
\hline \multicolumn{5}{|l|}{ Can read and write } \\
\hline Yes & $252(82.6)$ & 133 (81.6) & $119(83.8)$ & 0.612 \\
\hline No & $53(17.4)$ & $30(18.4)$ & $23(16.2)$ & \\
\hline \multicolumn{5}{|l|}{ Years of Schooling } \\
\hline Uneducated & $42(13.8)$ & $25(15.3)$ & $17(12.0)$ & \\
\hline 1 to 4 years & $181(59.3)$ & $91(55.8)$ & $90(63.4)$ & 0.397 \\
\hline 5 years or more & $82(26.9)$ & $47(28.8)$ & $35(24.6)$ & \\
\hline \multicolumn{5}{|l|}{ Occupational status } \\
\hline Works and/or retired & 59 (19.3) & $14(8.6)$ & $45(31.7)$ & $0.000^{*}$ \\
\hline Retired & $246(80.7)$ & $149(91.4)$ & $97(68.3)$ & \\
\hline \multicolumn{5}{|l|}{ Renda mensal } \\
\hline$\leq 1 \mathrm{MS}^{\&}$ & $227(74.4)$ & $113(69.3)$ & $114(80.3)$ & $0.029^{*}$ \\
\hline 2 or more MS & $78(25.6)$ & $50(30.7)$ & $28(19.7)$ & \\
\hline \multicolumn{5}{|l|}{$N^{\circ}$ of dependants } \\
\hline 1 person & $58(19.3)$ & $32(20.1)$ & $26(18.4)$ & \\
\hline 2 a 3 people & $223(74.3)$ & $120(75.5)$ & $103(73.0)$ & 0.340 \\
\hline 4 people or more & $19(6.3)$ & $7(4.4)$ & $12(8.5)$ & \\
\hline Total & $305(100)$ & $163(53.4)$ & $142(46.6)$ & \\
\hline
\end{tabular}

Note: ${ }^{*}$ Chi-square test; $p<0.05 .{ }^{8} \mathrm{MS}$ - Minimum salary $(R \$ 954.00)$.

\section{DISCUSSION}

The assessment of the clinical-functional dimensions of the elderly subjects demonstrated that there are positive predictive factors for the preservation of functional capacity, such as: higher education level and income, good health conditions and preserved mobility. However, there are predictive dimensions that can be considered negative for the maintenance of clinical-functional conditions, amongst them are advanced age, low educational level, reduced economic condition, poor or regular health status, impaired mobility capacity and cognitive impairment.

Thus, it was found that cognitive impairment can predict the development changes in clinical-functional conditions. That is, when frailty becomes a multidimensional entity, resulting from the interaction of biological, psychological and social factors over the course of life ${ }^{(18)}$, the elderly subjects were classified as robust, pre-frail and frail.

It is worth mentioning that robust elderly subjects are those who have a good homeostatic reserve and, therefore, can manage their life independently and autonomously and do not have functional disability or chronic health condition. Elderly people at risk of frailty (pre-frail) can manage their life independently and autonomously, however they are in a dynamic state between senescence and senility, resulting in the presence of functional limitations, but without functional dependence. A frail elderly person is one who presents an established functional decline and who is unable to manage his life, due to the presence of disabilities, single or multiple $\mathrm{e}^{(14)}$.

In the present study, 219 (71.8\%) of the total elderly subjects were classified as robust; and of these, 178 (77.7\%) had no cognitive impairment. However, of the 19 (6.2\%) elderly subjects classified as frail, the largest number, 13 (17.1\%), presented cognitive impairment, demonstrating a statistically significant association between cognition and functionality in the evaluated elderly. This same finding was also found in other studies ${ }^{(19-20)}$.

Regarding cognition, 34 (27.6\%) of the elderly with cognitive impairment mentioned that a family member or friend mentioned that they were becoming more forgetful, and deteriorating in the latest months. It is noteworthy that, of the elderly subjects without cognitive impairment, 7 (38.9\%) reported that forgetting is preventing the performance of some daily activity, and the same is true for 11 (61.1\%) elderly with cognitive impairment.

With increasing age, some cognitive functions remain stable and others decline. In this study, it was observed that 76 (24.9\%) elderly people had cognitive impairment. In different studies $^{(20-21)}$, there was a greater proportion of individuals, respectively, $28.14 \%$ and $63.3 \%$ of the elderly population with cognitive impairment. This differentiation may be associated with the characteristics of the interviewed elderly, because in those studies the sample consisted of individuals living in urban areas of a large city, whereas in this study, elderly subjects who participated were living in urban and rural areas, in a small municipality, this favored social interaction. It is also emphasized, that cognitive impairment also affects the individual's functional capacity in their daily lives, implying loss of independence and autonomy. Such loss varies according to the degree of severity, with a consequent reduction in the quality of life of the elderly, which indicates the importance of early diagnosis of cognitive decline ${ }^{(22)}$.

Regarding IADLs, 275 (90.2\%) of the elderly referred that their health or physical condition did not prevent them from shopping; and 283 (92.8\%) did not fail to control their money or pay bills. Among the elderly with cognitive impairment, 19 (86.4\%) reported having stopped shopping or paying bills because of their health condition. With regards to the performance of small domestic activities, 20 (71.4\%) stopped doing them. For basic activities of daily living (ADLs), such as bathing alone, 296 (97.0\%) reported not having stopped doing them. This data is similar to the study that assessed the functional capacity for ADL of elderly residents in rural areas, which concluded that the elderly, for the most part, were functionally capable to perform them, both basic and instrumental, in which the prevalence of capacity for ADL it was 81.8\%; and for IADLs, 54.6\%(23).

Regarding mood, it was observed that 74 (24.3\%) of the elderly referred to discouragement, sadness or hopelessness in the last month. This data is relevant, as it may be associated with a depressive condition. Studies highlight the importance of the predictive relationship between depressive symptoms and 
functional disability, making the strategy of tracking common symptoms in the elderly important. Such symptoms are often unknown - such as changes in mood, sleep and appetite - and remain for more than two or three weeks ${ }^{(24-25)}$.

As for mobility, 32 (10.5\%) elderly subjects reported difficulties to walk, and 294 (96.4\%) of the total of elderly subjects did not have two or more falls in the last year. This data draws attention, as they diverge from another study, carried out with the objective of verifying the factors associated with falls in the elderly, in which the authors verified an incidence of recurrent falls in $75 \%$ of the investigated elderly subjects, being linked to the cognitive condition, changes visual impairments, vestibulopathies and the home environment. And the isolated factors that did not present risks were balance, gait and muscle strength ${ }^{(26)}$.

The sociodemographic data demonstrated that 293 (96.1\%) elderly subjects did not mention vision problems capable of preventing the performance of some daily activity, and 292 $(95.7 \%)$ also did not report hearing problems. However, of the elderly subjects with cognitive impairment, 8 (61.5\%) reported hearing problems, corroborating the findings of the study carried out with the aim of verifying the correlation between cognitive performance and hearing loss, which demonstrated that cognition may be intimately related to the communicative performance of the elderly subjects in unfavorable conversational situations - for example, when there is hearing loss ${ }^{(27)}$.

Sociodemographic data shows that there was a predominance of elderly people aged 60 to 70 years old, data that also appear in other studies ${ }^{(28)}$. It should also be noted that $44(14.4 \%)$ of the elderly were aged 80 years or more. This age group, 80 years old or more, has been growing at a relatively higher rate than the total elderly population, presenting a growth of $246 \%$, in the period between 1980 to $2005^{(29)}$. The highlight for the female population may be related to the greater longevity of women, the fact that characterizes the feminization of aging.

Regarding education, there was a prevalence of those who studied between one and four years, data similar to other studies ${ }^{(30)}$. These results are in line with the data collected by the IBGE ${ }^{(11)}$, showing a high incidence of low levels of education among the elderly in Brazil. In this same context, it was found that the elderly subjects with a higher level of education, in their majority, were classified as robust, that is, they had better clinical-functional capacities, therefore it is important to note that education has an impact on the population's health situation. The elderly subjects with higher levels of education are more autonomous for self-care, the use of means of transport and communication. On the other hand, the elderly subjects with lower levels of education are more susceptible to diseases and, therefore, demand greater attention to health and recognition of this important factor. The influence of socioeconomic aspects in this context is emphasized, because, during the childhood of many of these elderly people, education was the privilege of a few ${ }^{(29)}$.

Thus, the results of this study reinforce the understanding that cognitive ability is associated with the individual's functionality. This finding must be considered in the construction of prevention strategies to ensure, as much as possible, the independence and autonomy of the elderly ${ }^{(28)}$.

Although the largest number of elderly subjects who participated in this study was classified as robust, care must be taken to adopt measures to preserve the functional and cognitive capacities of this population stratum. This is because such conditions must be maintained with a view to maintaining the autonomy and independence of the elderly people.

\section{Study limitations}

This study shows limitations in relation to the inter-individual variability of the elderly, using indirect methods for assessing outcomes. Also, other variables were not evaluated in the present study, because it understands that they can influence the conditions of clinical-functional decline as well as cognitive capacity, since they were considered secondary outcomes and were not part of the objective of this manuscript. Another limitation was the fact that it was carried out with the resident population of a small municipality. Therefore, it is suggested that other studies should be conducted with samples from different municipalities.

\section{Contributions to the field of nursing}

From the results found, it is evident that nursing deals with the elderly in different settings, so it should act in both maintaining the clinical-functional and cognitive conditions of robust and pre-frail elderly people and attending to the rehabilitation of the disabilities installed in those elderly people who are in a situation of frailty.

\section{CONCLUSION}

The elderly subjects were classified as robust, pre-frail and frail, with a greater predominance of robust. With regards to cognitive ability, it was found that most elderly subjects maintained their cognition unchanged. Yet, it was possible to show that cognitive impairment can predict the development of functional disabilities, since, among the elderly subjects classified as fragile, there was a predominance of those with cognitive impairment. Also, it was found that the elderly with a higher level of education, were those who were classified as robust predominately, in other words, they had better functional capacity.

Therefore, it was found that, among the positive predictive dimensions for maintaining clinical-functional conditions, are: higher education level and income, good health conditions and preserved mobility. Among the dimensions that can be considered negative are: advanced age, low education level, reduced economic condition, poor or regular health status, impaired mobility capacity and cognitive impairment.

Results that show the association between cognitive impairment and functional capacity point to the importance of carrying out studies that track such conditions in the elderly population, with a view to planning health care actions, maintaining health, independence, autonomy and quality of life of the elderly. 


\section{REFERENCES}

1. Silva AP, Pirolo SM. Perception of man about aging. Rev Enferm UFPE[Internet]. 2017 [cited: 2018 May 08];11(supl.3):1388-97. Available from: https://periodicos.ufpe.br/revistas/revistaenfermagem/article/viewFile/13981/16832

2. Gonçalves CD. Envelhecimento bem-sucedido, envelhecimento produtivo e envelhecimento ativo: reflexões. Estud Interdiscipl Envelhec[Internet]. 2015[cited 2018 Sep 12];20(2):645-57. Available from: https://seer.ufrgs.br/RevEnvelhecer/article/view/49428

3. Santos GS, Cunha ICKO. Avaliação da qualidade de vida de mulheres idosas na comunidade. Rev Enferm Cent O Min. 2014;4(2):1135-45. doi: 10.19175/recom.v0i0.593

4. Organização Mundial de Saúde (OMS). Envelhecimento ativo: uma política de saúde. Brasília: Organização Pan-Americana da Saúde. 2005.

5. Saquetto M, Schettino L, Pinheiro P, Sena ELS, Yarid SD, Gomes Filho DL. Aspectos bioéticos da autonomia do idoso. Rev Bioét. 2013;21(3):518-24. doi: 10.1590/S1983-80422013000300016

6. Ilha S, Argenta C, Silva MRS, Cezar-Vaz MR, Pelzer MT, Backes DS. Envelhecimento ativo: reflexão necessária aos profissionais de enfermagem/saúde. Rev Pesqui: Cuid Fundam. 2016;8(2):4231-42. doi: 10.9789/2175-5361.rpcfo.v8.4242

7. Maciel GMC, Santos RS, Santos TM, Menezes RMP, Vitor AF, Lira ALBC. Avaliação da fragilidade no idoso pelo enfermeiro: revisão integrativa. Rev Enferm Cent O Min. 2016;6(3):2430-38. doi: 10.19175/recom.v6i3.1010

8. Buckinx F, Rolland Y, Reginster JY, Ricour C, Petermans J, Bruyère $O$. Burden of frailty in the elderly population: perspectives for a public health challenge. Arch Public Health. 2015;73(1):19. doi: 10.1186/s13690-015-0068-x

9. Cesari M, Prince M, Thiyagarajan JA, Carvalho IA, Bernabei R, Chan P, et al. Frailty: an emerging public health priority. J Am Med Dir Assoc. 2016;17(3):188-92. doi: 10.1016/ j.jamda.2015.12.016

10. Melo BRS, Diniz MAA, Casemiro FG, Figueiredo LC, Santos-Orlandi AA, Haas VJ, et al. Avaliação cognitiva e funcional de idosos usuários do serviço público de saúde. Esc Anna Nery. 2017;21(4):e20160388. doi: https://doi.org/10.1590/2177-9465-ean-2016-0388

11. Martins JB, Lange C, Lemões MAM, Llano PMP, Santos F, Avila JA. Avaliação do desempenho cognitivo em idosos residentes em zona rural. Cogitare Enferm. 2016;21(3):01-09. doi: 10.5380/ce.v21i3.48943

12. Andriolo BNG, Santos NV, Volse AA, Fé LCM, Amaral ARC, Carmo BMSS, et al. Avaliação do grau de funcionalidade em idosos usuários de um centro de saúde. Rev Soc Bras Clin. Med. 2016;14(3):139-44.

13. Instituto Brasileiro de Geografia e Estatística (IBGE). Censo Demográfico. 2010.

14. Moraes EM, Carmo JA, Moraes FL, Azevedo RS, Machado CJ, Montilla DER. Índice de Vulnerabilidade Clínico Funcional-20 (IVCF-20): reconhecimento rápido do idoso frágil. Rev Saúde Pública. 2016;50(81):1-10. doi: 10.1590/s1518-8787.2016050006963

15. Bertolucci PHF, Brucki SMD, Campacci SR, Juliano Y. O mini-exame do estado mental em uma população geral. Impacto da escolaridade. Rev Arq Neuropsiquiatr. 1994;52(1):1-7. doi: 10.1590/S0004-282X1994000100001

16. Melo DM, Barbosa AJG. O uso do Mini-Exame do Estado Mental em pesquisas com idosos no Brasil: uma revisão sistemática. Ciên Saúde Coletiva. 2015;20(12):3865-76. doi: 10.1590/1413-812320152012.06032015

17. Ministério da Saúde (BR). Conselho Nacional de Saúde. Resolução n. 466, de 12 de dezembro de 2012. Aprova diretrizes e normas regulamentadoras de pesquisas envolvendo seres humanos. Brasília, Diário Oficial da União, 2012.

18. Campos DM, Felippe LA. Profile of the frailty in the elderly participants of an assisting living residence in Campo Grande-MS. J Health Sci [Internet] 2016 [cited 2018 Oct 20];18(4):224-8. Available from: http://pgsskroton.com.br/seer/index.php/JHealthSci/ article/view/4511/3404

19. Converso MER, lartelli I. Caracterização e análise do estado mental e funcional de idosos institucionalizados em instituições públicas de longa permanência. J Bras Psiquiatr. 2007;56(4):267-72. doi: 10.1590/S0047-20852007000400005

20. Cruz DT, Cruz FM, Ribeiro AL, Veiga CL, Leite ICG. Associação entre capacidade cognitiva e ocorrência de quedas em idosos. Cad Saúde Colet. 2015;23(4):386-93. doi: 10.1590/1414-462X201500040139

21. Andrade NB, Novelli MMPC. Perfil cognitivo e funcional de idosos frequentadores dos Centros de Convivência para idosos da cidade de Santos, SP. Cad Ter Ocup UFSCar. 2015;23 (1):143-52. doi: 10.4322/0104-4931.ctoAO396

22. Machado JC, Ribeiro RCL, Cotta RMM, Leal PFG. Declínio cognitivo de idosos e sua associação com fatores epidemiológicos em Viçosa, Minas Gerais. Rev Bras Geriatr Gerontol. 2011;14(1):109-21. doi: 10.1590/S1809-98232011000100012

23. Pinto AH, Lange C, Pastore CA Llano PMP, Castro DP, Santos F. Capacidade funcional para atividades da vida diária de idosos da Estratégia de Saúde da Família da zona rural. Ciênc Saúde Coletiva. 2016; 21(11):3545-55. doi: 10.1590/1413-812320152111.22182015

24. Matias AG, Fonsêca MA, Gomes ML, Matos MA. Indicadores de depressão em idosos e os diferentes métodos de rastreamento. Einstein. 2016;14(1):6-11. doi: 10.1590/S1679-45082016AO3447

25. Bretanha AF, Facchini LA, Nunes BP, Munhoz TN, Tomasi E, Thumé E. Depressive symptoms in elderly living in areas covered by Primary Health Care Units in urban area of Bagé, RS. Rev Bras Epidemiol. 2015;18(1):1-12. doi: 10.1590/1980-5497201500010001

26. Piovesan AC, Pivetta HMF, Peixoto JMB. Fatores que predispõem a quedas em idosos residentes na região oeste de Santa Maria, RS. Rev Bras Geriatr Gerontol. 2011;14(1):75-83. doi: 10.1590/S1809-98232011000100009 
27. Soares E, Coelho MO, Carvalho SMR. Capacidade funcional, declínio cognitivo e depressão em idosos institucionalizados: possibilidade de relações e correlações. Rev Kairós Gerontol. 2012;15(5):117-39. doi: 10.23925/2176-901X.2012v15i3p117-139

28. Pereira DS, Nogueira JAD, Silva CAB. Quality of life and the health status of elderly persons: a population-based study in the central sertão of Ceará. Rev Bras Geriatr Gerontol. 2015;18(4):893-908. doi: 10.1590/1809-9823.2015.14123

29. Inouye K, Pedrazzani ES, Pavarini SCl. Octogenários e cuidadores: perfil sócio-demográfico e correlação da variável qualidade de vida. Texto Contexto Enferm. 2008;17(2);350-7. doi: 10.1590/S0104-07072008000200018

30. Carneiro JÁ, Ramos GCF, Barbosa ATF, Mendonça JMG, Costa FM, Caldeira AP. Prevalence and factors associated with frailty in noninstitutionalized older adults. Rev Bras Enferm. 2016;69(3):408-15. doi: 10.1590/0034-7167.2016690304i 